\title{
ARABIC INSCRIPTIONS IN THE CAPPELLA PALATINA: PERFORMATIVITY, AUDIENCE, LEGIBILITY AND ILLEGIBILITY נפ
}

Jeremy Johns

\section{INTRODUCTION: ARABIC INSCRIPTIONS IN NORMAN SICILY}

The twelve sons of Tancred, baron of Hauteville in Normandy, who crossed the Alps in the mid eleventh century and became leaders of the Normans in Southern Italy and ancestors of the kings of Sicily, were men of war, not of letters. Nonetheless, the younger of them soon acquired the epigraphic habit, and by the Io8os, Latin, Greek and Arabic texts were regularly issued in their names. For example, Robert Guiscard appeared as a duke of imperial Rome in the Latin text on the façade of Salerno Cathedral, ${ }^{\mathrm{I}}$ as a Byzantine duke in the Greek inscription from San Pietro de Balnearis in Palermo dated to the year 6589 in the era of Constantinople, ${ }^{2}$ and as abārt al-dūqa al-ajall malik siqillìya ('Robert, the mighty duke, the ruler of Sicily') in the Arabic legend in the field of a tari minted at Palermo in the year 464 of the hijra (1072 CE). ${ }^{3}$ It is highly unlikely that Robert would himself have been able to read any of these texts. Indeed, the persistence of the exclusively Islamic profession of faith on the obverse of the Palermo tari of 1072 seems to indicate that neither Robert nor his Christian officials could have been aware, even at second hand, of the content of the Arabic legends. ${ }^{4}$ Thus it seems clear that, from the outset, such inscriptions were less important for their content than as demonstrations that the Norman conquerors had appropriated the languages, scripts and styles of the previous rulers of the South. ${ }^{5}$ Such assertions of the legitimacy of their rule over all their new subjects and territories served primarily as nonliterary signifiers of the triumphant appropriation of what are arguably the most immediately distinctive visual cultural identifiers of the communities conquered and now ruled by the Normans. The distinctively 
different scripts of Arabic, Greek and Latin were used in this way throughout the brief reign of the De Hautevilles to symbolise the three dominant cultures of the South - Arabic for the Muslims, Greek for the Greek Orthodox Christians, and Latin for the Christians who followed the rite of Rome. Even after the collapse of the dynasty and the succession of the Hohenstaufen emperor Henry VI, his panegyrist, Peter of Eboli, would still describe Palermo as 'a happy city, blessed with a three-tongued people', and would visualise that populace as the trilingual royal chancery with its Greek, Saracen and Latin scribes side by side, each writing his own distinctive script. ${ }^{6}$

The earliest Norman inscriptions had essentially continued or revived the epigraphic practices of the earlier rulers of the South, but with the coronation of Robert Guiscard's nephew, Roger, as the first king of the new kingdom of Sicily on Christmas Day i z 30 , a new deliberately heterogeneous royal art and architecture began to be assembled and developed. This new style did not perpetuate an indigenous Sicilian tradition inherited from the previous rulers of the island, but rather depended upon the importation of art and artists from the contemporary Mediterranean - Byzantium, Rome and, most relevant here, the Islamic Mediterranean, especially Fatimid Cairo but also the Berber emirates that succeeded the Fatimids in the central Maghrib, the Zirids and the Hammadids, and the Almoravids of Morocco. From this time, new styles of Arabic epigraphy were introduced and began to be developed that reflected contemporary usage and did not hark back to the Kalbid past in Sicily. Under King Roger and his successors, such new Arabic texts came to be used systematically to project, enhance and manage the royal image both on royal buildings and on the ceremonial vestments worn by the king in the churches, palaces and processions where he was displayed to his subjects, and on his coins and documents that reached even the most remote corners of his kingdom. ${ }^{7}$

The Norman kings and their ministers systematically employed bilingual, trilingual and, in one famous surviving example ${ }^{8}$ quadrilingual texts to convey the message that the cohesive power of the Norman ruler had bound together the different cultures and peoples of the kingdom into a single Sicilian people, the populus trilinguis. Eugenius of Palermo, the Greek minister and panegyrist of William II, expressed that claim in these words: 'Do not you [the king] harmonise the inharmonious, and mix together the unmixable ... with wise foresight blending and uniting into a single race disparate and incongruent peoples'. 9 Arabic, Greek and Latin texts were systematically contraposed both on single artefacts such as bilingual coins from the royal mint, bilingual documents from the royal chancery, bilingual inscriptions on regalia from the royal wardrobe, and trilingual inscriptions on royal monuments - and in single architectural settings, such as the great royal churches of which Cefalù, the Cappella Palatina and Monreale survive largely intact. By far the richest and most interesting example of this purposeful contraposition of text is the Cappella Palatina, where the Greek and 


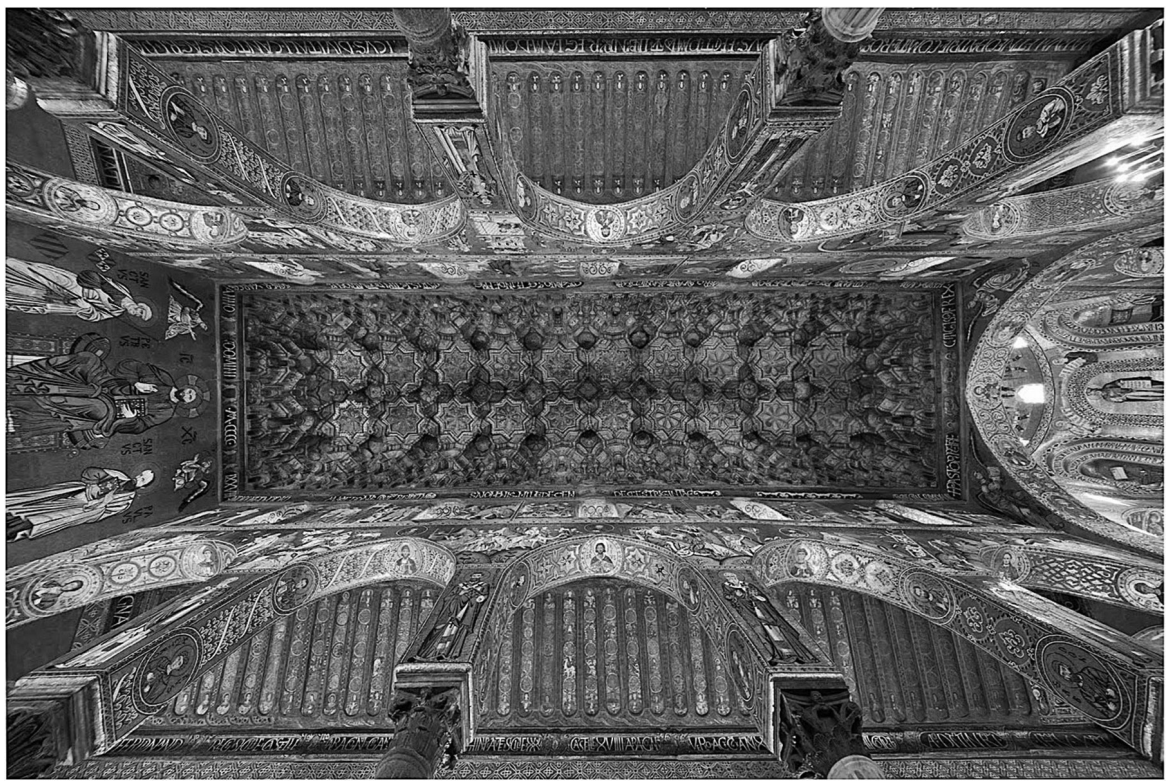

39. Palermo, Palazzo Reale, Cappella Palatina. The painted wooden ceilings of the nave and the two aisles, seen from below. (After Brenk, ed., 2010, 4, unnumbered figure before p. 384 . Photo Ghigo Roli (C) 20 Io Franco Cosimo Panini Editore Spa)

Latin inscriptions of the mosaics are set against the Arabic texts of the painted ceilings of the nave and two aisles (Fig. 39), of the doors and of the moveable objects used within the chapel. ${ }^{\text {Io }}$ Although in what follows discussion focuses upon the Arabic inscriptions of the Cappella Palatina, ${ }^{\text {II }}$ the multilingual background against which they are set in the chapel, as well as in the royal art and architecture of Norman Sicily as a whole, is not ignored.

A very few words here suffice to introduce the content of the Arabic inscriptions of the Norman kings, which may be divided into three distinct groups. One commemorates acts of construction, including the trilingual inscription from a public building in Termini Imerese overseen by King Roger's eunuch PeterBarrūn, ${ }^{\mathrm{I} 2}$ and the trilingual inscription from King Roger's water-clock now displayed outside the entrance to the Cappella Palatina. ${ }^{13}$ A second group comprises panegyric verses that once decorated the royal palaces, including the opus sectile inscriptions from the Cappella Palatina (Fig. 40), ${ }^{14}$ and from Roger's lost palace in Messina. ${ }^{15}$ The third group consists of supplications (ad'iya) made to God that he may bestow upon the king a variety of blessings, qualities and virtues. This last group is the largest to survive and is represented by the inscription embroidered in gold on the hem of King Roger's mantle, ${ }^{16}$ by the inscription from the bell tower of the lost royal church of San Giacomo la Mazara, ${ }^{17}$ and most importantly - by the Arabic inscriptions from the painted ceilings of the Cappella Palatina (Fig. 4I). ${ }^{\mathrm{I} 8}$ 

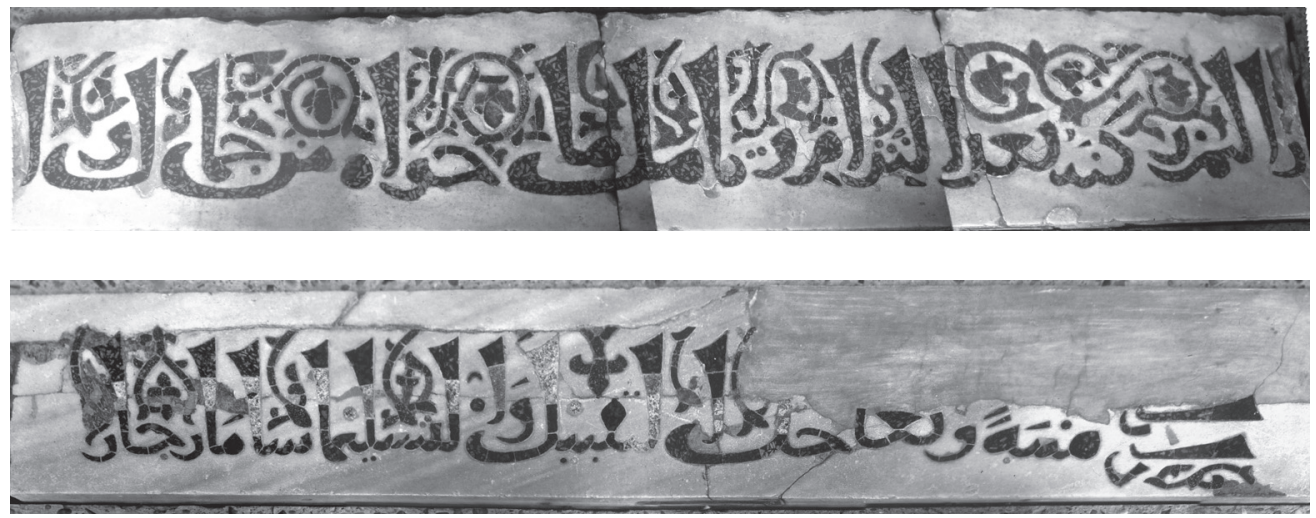

40. Palermo, Galleria Nazionale della Sicilia, inventory nos. 5 104 \& 5105. The two longest of the three fragments of Arabic verse inscriptions in opus sectile from the Cappella Palatina. (Photo Jeremy Johns (C) 2010 Jeremy Johns)

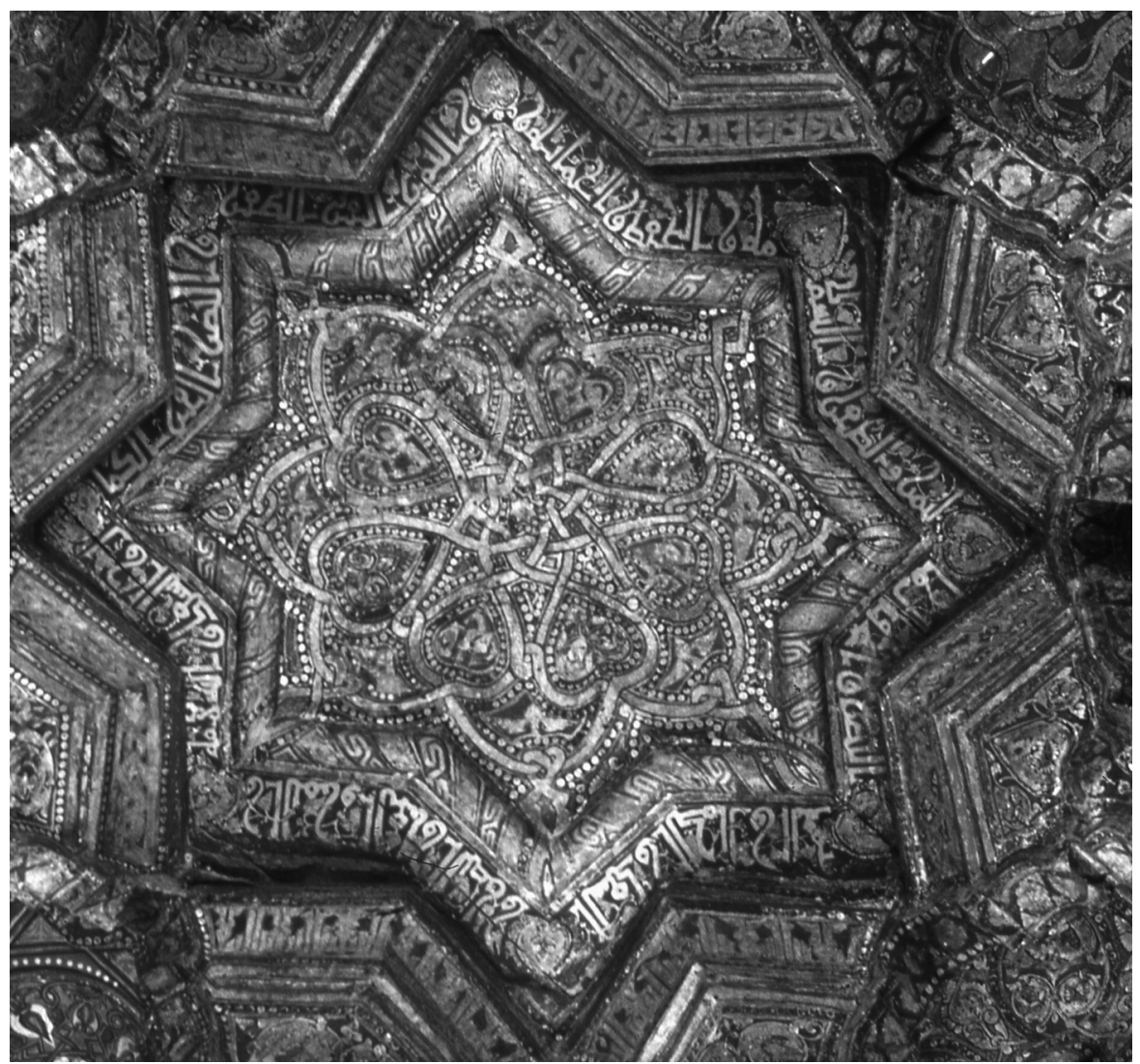

4I. Palermo, Palazzo Reale, Cappella Palatina. Detail of a stellate coffer (south side, third from west) from the central zone of the painted wooden ceiling of the nave. (Khalili Research Centre Archive, Slide no. ISL 15777 . (C) 2010 University of Edinburgh \& The Barakat Trust) 


\section{ARABIC INSCRIPTIONS IN THE CAPPELLA PALATINA}

The principal palace of the Norman kings in Palermo, built on the highest point within the walls on the site of the acropolis of the ancient city and replacing a palace of the Kalbid emirs, was extensively rebuilt and enlarged by King Roger and his successors. The structure now known as the Cappella Palatina was built on the first floor of an inner court and rested directly upon the vaulted roof of an earlier and smaller chapel of St. Peter. The structural history of the Cappella Palatina is complex and still highly problematic and controversial. However, it is now generally accepted that it was originally intended to combine a sanctuary in the east end with a three-aisled basilical hall extending westwards from the sanctuary, with a platform for the royal throne in the centre of its western wall. The manner in which these two elements - a sanctuary for the celebration of the divine liturgy oriented from west to east, and a royal hall focused upon the king enthroned in the west end - actually functioned is far from clear and may have changed and developed over time as King Roger and his successors adapted the original plan, altered the structure and added to its decoration. At the time of its consecration, probably in June I I43, the walls, vaults and central cupola of the sanctuary were extensively decorated with mosaics, while the walls of the western hall seem to have been undecorated below the elaborately painted wooden ceilings (Fig. 39) and above the polychrome opus sectile pavements and dadoes. Although earlier scholarship tended to make a clear distinction between the 'Byzantine' mosaics of the sanctuary and the 'Islamic' ceilings and pavements of the western hall, recent studies have tended to speculate that there was from the outset a programme that unified the two elements; these studies have attempted to reconstruct detailed examples of the ways in which the mosaics of the sanctuary were intended to collaborate with the ceilings and pavements of the western hall in the projection of a single royal programme. ${ }^{19}$

Today, the Arabic inscriptions that survive in the Cappella Palatina can scarcely be seen in the upper reaches of the painted ceilings of the western hall (Figs. 39 \& 4I), but it is likely that, in the early I I 4Os before its mosaics were set, Arabic epigraphy would have been the most immediately conspicuous decorative element of the royal hall. The doors leading into the hall were furnished with metal handles decorated with Arabic supplications ( $a d^{\text {' }}$ iya). ${ }^{20}$ Inside, the doors may have been framed by white marble panels inlaid with porphyry and serpentine opus sectile inscriptions reciting Arabic panegyric verses in praise of King Roger. ${ }^{21}$ After the nave mosaics were completed, ${ }^{22}$ the gap between their upper border and the lower border of the wooden ceilings was covered by the tall wooden cornices, now overpainted with Latin texts commemorating restorations commissioned by the kings of Aragon, but in all likelihood originally bearing Arabic inscriptions. ${ }^{23}$ Above them, hundreds of panels in the wooden ceilings were painted with Arabic inscriptions and pseudo-epigraphic designs. ${ }^{24}$ Even the furnishings of the chapel would have been decorated with Arabic texts: the ivory chests and 
reliquaries, such as the famous incrusted casket still conserved in the treasury with its long inscriptions; ${ }^{25}$ the textile hangings on the walls and the curtains in the arches of the arcades; ${ }^{26}$ the liturgical cloths, vestments, vessels and plate; and the glass lamps suspended from the ceiling ${ }^{27}$ - all would have borne Arabic inscriptions. So, too, would the vestments of the king and his courtiers and servants, and the cushions and carpets upon which they sat. ${ }^{28}$ The original location of the water-clock that bore the trilingual inscription that is now displayed on the wall outside the Cappella Palatina is unknown, but if it was originally associated with the royal chapel, then it proclaimed King Roger's mastery of not just the three cultures of his kingdom but also of time itself. ${ }^{29}$ And, if the famous trilingual psalter in the British Library (MS Harley 5786) was indeed used in the royal chapel, then the liturgy was sung there in Arabic, just as it undoubtedly was in Greek and in Latin, and that psalter together with other Arabic liturgical texts may also have been kept in the chapel. $3^{\circ}$

Such a proliferation of Arabic texts in the Cappella Palatina may today be difficult to imagine, and it may help to recall that, for centuries before the rise of Islam and thereafter until today, Arabic was one of the languages of Christianity. After the Islamic conquests and the spread of Arabic as the language of government, learning and commerce throughout much of the Mediterranean, many indigenous Christian communities from Spain to the Tigris adopted that language for common usage and even came to worship in Arabic. In Norman Sicily, many Greek Orthodox Christians were Arabic speakers, and many leaders of their community were prominent in and around the royal court. Amongst them were both immigrants from the Islamic Mediterranean and the descendants of South Italians and Sicilians who had adopted Arabic under Islamic rule. Chief amongst the former was George of Antioch, King Roger's first minister and the main architect of his multicultural monarchy. When George built Santa Maria dell'Ammiraglio at about the same time as the Cappella Palatina or perhaps slightly before it, ${ }^{3}$ he placed an Arabic inscription in the drum of the dome: painted on sixteen wooden boards, it recited the Epinikion Hymn from the Anaphora and the Great Doxology, corresponding to the Sanctus of the Roman liturgy. The Archangels, who are depicted in the mosaics of the dome prostrating themselves before the throne of Christ Pantokrator, are thus seen to worship Him by singing the hymn of victory that is written in Arabic immediately beneath their feet. ${ }^{32}$

The status of Arabic as a Christian language may perhaps have facilitated the appropriation of Arabic by a Christian king. However, the content of most royal inscriptions was not explicitly Christian, but rather deliberately appropriated Islamic texts and employed them to serve the Norman ruler. In the Arabic supplications ( $a d^{\text {' }}$ iya), a series of royal qualities and virtues that were typically invoked mina llāb ('from God') were here summoned on behalf of the Christian king. In the opus sectile inscriptions in the Cappella Palatina (Fig. 40), the royal palace is figured as the $\mathrm{Ka}$ ' $\mathrm{ba}$ at Mecca, whereas the reader is imagined as a Muslim pilgrim and his acts of homage and submission to King Roger are 
described in terms proper to the sacred rituals of the Islamic bajj. ${ }^{33}$ This was no syncretistic attempt to reconcile Christianity and Islam, but rather a masterful act of cultural appropriation intended to enhance the image of the king, of precisely the kind that Ibn Jubayr was to see as evidence of the Norman king's 'ability', one that he perceived as a dangerous threat to Islam. ${ }^{34}$

\section{PERFORMATIVITY}

No primary source independent of the Arabic inscriptions that decorate the Cappella Palatina suggests that they prescribed the encounter between the viewer and the building. Nor does the location and display of those Arabic inscriptions that survive in situ suggest that they could have guided or led the viewer around the building. Nonetheless, the content of one group of inscriptions and a figural scene incorporating part of another group do suggest that the Arabic inscriptions referred to ceremonies and rituals that were appropriated by the Norman king and that, if they were not actually performed in the royal hall in the western end of the chapel, were at least explicitly evoked by the texts.

The three fragments of inscriptions in opus sectile from the Cappella Palatina are all that survive from what was clearly once an extensive programme of Arabic verse inscriptions that decorated King Roger's palace in Palermo. ${ }^{35}$ It is almost inconceivable that these verses would not have been recited in front of the king, at least on the occasion of their installation or of the inauguration of the hall, although no witness has left a record of such a public performance of their content. It is not known for certain where the inscriptions were originally located, but their provenance, form and content all suggest that they originally framed doorways leading to the royal hall in the western end of the Cappella Palatina. The smallest of the three is too fragmentary to read and translate with confidence, but the other two fragments may be transcribed and rendered as follows:

Fig. 40A (metre ramal)

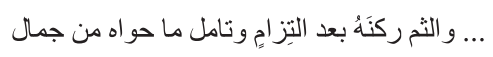

I....

[... wa-]lthim ruknahū ba 'da ltizāmin * wa-ta'ammal mā ḅawāhū min jamā̄ $\bar{a}$ wa $[\ldots]$

[... and] kiss its corner after pressing yourself [to it] $*$ and contemplate the beauties that it contains.

And...........

Fig. 4०B (metre kāmil)

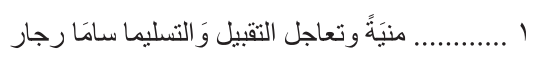




\section{I. [...] munyatan* wa-tu 'äjilu l-taqbìla wa-l-tastīmā sāmā Rujāru [...] \\ 2. dār a [l-...]}

I. [...] an object of desire * and you hurry to give the kiss and to make the submission. Roger has sought to surpass [...]

2. The house of $[\ldots]$

Both contain a series of explicit references to the ceremonies of the tawa $f$ that form part of the bajj or Islamic pilgrimage to Mecca. The pilgrim must circumambulate the $\mathrm{Ka}$ ' $\mathrm{ba}$ seven times, keeping it always on his right and beginning and ending at the Black Stone that is set into its eastern corner (rukn; cf. A, rukn). The first three circuits must be performed at the rapid pace called ramal - the name of the 'running' metre in which the verses of A were composed - and the last four, at a normal pace. Each time he passes it, the pilgrim should make a special effort to kiss (taqbìl; cf. B, al-taqbīl) the Black Stone or at least to touch it (istilām; cf. B, al-taslìm). After he has completed seven circuits, in order to acquire a special blessing, the pilgrim presses himself against al-multazam (cf. A, iltizām), a stretch of the wall of the Ka' ba between the door and the Black Stone, drinks from the holy well of Zamzam, and finally kisses the Black Stone in farewell (note the sequence; cf. A, "kiss its corner after pressing yourself to it"). In these verses, King Roger's hall becomes the $\mathrm{Ka}$ ' $\mathrm{ba}$, and the reader is figured as a pilgrim whose acts of homage and submission to the king and his palace are represented as the sacred ceremonies of the bajj.

This depiction seems to go beyond the common literary trope in which a visitor is compared to a pilgrim and his destination to the $\mathrm{Ka}$ ' ba: it seems highly likely that these verses were inspired by a panegyric addressed to the Fatimid caliph in which his palace was similarly figured as an analogue of the $\mathrm{Ka}$ ' $\mathrm{ba}$. Indeed, the hypothesis that best accounts for the presence of such inscriptions in the Cappella Palatina is that they imitated similar inscriptions that once decorated the lost Fatimid palaces of Cairo. There is some reason to think that visitors to the Fatimid court may have been obliged to embrace and to kiss the gates of the palace in a ritual intended to act out the idea that, just as the imām was God's representative on earth (kbaliffat Allāb), so was his palace the analogue of the House of God (Bayt Alläh) in Mecca.

Could it be that the inscriptions in the Cappella Palatina similarly prescribed the rituals that visitors to King Roger's palace were expected to perform? This is precisely what the texts claim to do. In fragment A, the verbs ilthim ('kiss') and ta 'ammal ('contemplate') are both in the imperative mood addressed to a singular masculine subject, whereas the indicative verb ( $t u$ 'äilu 'you hurry') in fragment $\mathrm{B}$ also has a masculine second-person singular subject, so that the verses address the reader directly and instruct him to perform these rites. What is more, some of the surviving fragments of the Arabic verses in the opus sectile inscriptions from Messina direct a specific group of visitors to King Roger's palace: ya ma 'shara 
l-mulki dkbulū-bu fa inna-bu dāru l-kbulūd ('Enter, o nobles of the kingdom, for it [the palace] is the abode of eternal life'). ${ }^{36}$ Difficult as it is to imagine that King Roger's Norman barons would have performed such rites, it is conceivable that his crypto-Muslim servants and Greek Christian ministers, who had been educated and trained within the palace and would have been familiar with comparable ceremonies from Byzantine and Islamic courts, did actually perform them. The question remains open, but another piece of evidence suggests that other ceremonies, which the Norman barons would have found no less outlandish, may have been performed in the royal hall.

The largest corpus of Arabic inscriptions in the Cappella Palatina comprises the $a d^{\text {' }}$ iya or supplications made to God that he may bestow upon the king a variety of blessings, qualities and virtues. A flavour of these may be had from one of the kufic inscriptions painted in white that form the borders of the star-shaped coffers of the central part of the ceiling of the nave (Fig. 4I): alnașr wa-l-iqbāl wa-l-yumn wa-l-zafar wa-l-salāma wa-l-hifž wa-l-ḅimāya wa-l-yumn al- 'izz al-zafar wa-l-naṣr al- 'izz al-kamāl wa-l-sa'd wa-l-saläma wa-l-yumn wal- 'izz wa-l-nașr wa-l-sa'd wa-l-kamāl wa-l-i[jläl/fdāl/qbāl ?] ('victory and propitious-fate and bliss and attainment and security and vigilance and protection and bliss and power, attainment and victory, power, perfection and good-fortune and security and bliss and power and victory and good-fortune and perfection and [magnificence/generosity/propitious-fate ?]'). 37

Eighteen of the twenty-six ad'iya (not counting the adjectives) used in the Cappella Palatina appear ubiquitously throughout the medieval Islamic world in supplicatory inscriptions, especially on portable objects such as ceramics, ivories, metalwork and textiles, but also on buildings. ${ }^{3}$ Hjalmar Torp was therefore almost certainly mistaken in asserting that the ad 'iya in the Cappella Palatina are merely translations into Arabic of Byzantine acclamations. ${ }^{39}$ Nonetheless, the possibility remains that these $a d^{\prime}$ ' $y a$ were indeed recited in the royal hall of the Norman kings. Although no contemporary source describes any such ceremonial, a unique panel in the painted ceiling of the nave of the Cappella Palatina may depict just such a scene of acclamation (Fig. 42). It is located immediately to the north of the throne platform in the west end of the hall at the base of the first large unit of the muqarnas zone of the north side, beneath a pair of panels depicting seated rulers. ${ }^{4}$ In good light, a viewer blessed with perfect eyesight could have read the scene (but not, I dare say, the inscription) from the pavement of the hall and from the throne platform itself. The panel is occupied by a male half-figure, fully frontal, his eyes turned upwards, bearded and with long dark hair falling over his shoulders. His two arms are outstretched and in each of his closed fists he holds a cross. He wears a robe with decorated golden armbands and cuffs, and with an unusually elaborate golden band around the neck that falls vertically down the chest. The folds of the fabric of his robe are indicated by fine white lines that form concentric oblong swirls at the bottom of his torso, raising 


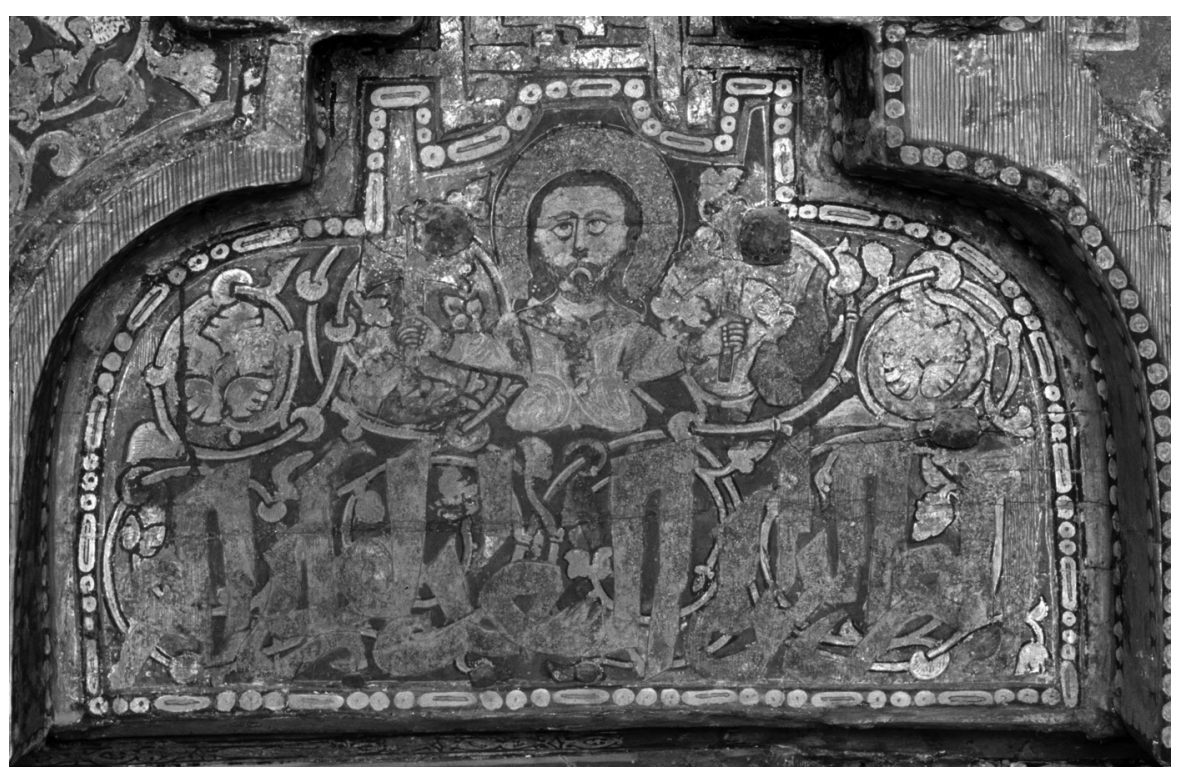

42. Palermo, Palazzo Reale, Cappella Palatina. Detail of panel at the base of the first large unit of the muqarnas zone from the west end on the north side of the ceiling of the nave, showing a male half-figure holding two crosses, above an Arabic inscription. (Khalili Research Centre Archive, Slide no. ISL 15 197. (C) 2010 University of Edinburgh \& The Barakat Trust)

the possibility that the artist may have intended to represent the figure on his knees; if not, then the figure is truncated at the waist in a peculiarly arbitrary fashion. Below the figure, a single line of Arabic in cursive script runs the full width of the panel, reciting the rhyming couplet of al- 'izzal-da' im al-sa ' $d$ al-qa' 'im al'izz... ('lasting power, established good fortune, ... power...'). The artist was unable to fit the adjectival complement of the final noun ( $a l-$ ' $i z z$, 'power') into the panel, but there can be no doubt that it was either $a l-d \bar{a}$ 'im ('enduring') or $a l-q \bar{a}$ ' im ('established'); this couplet is the most frequently repeated phrase in the Arabic inscriptions of the ceilings.

This is the only instance in which a $d u^{\prime} \bar{a}$ is associated with a figurative scene, and it is the only figurative scene to incorporate a formal text. ${ }^{{ }^{\mathrm{I}}}$ The pair of hand-crosses displayed by the figure suggest that the panel may depict a ceremony that was related to Byzantine benedictory rituals featuring a pair of handheld blessing-candles (dikêrion), which developed from first imperial and then patriarchal ceremonies in the tenth to twelfth centuries. ${ }^{42}$ The unique association of this scene with written ad'iya suggests that the ceremony evoked is likely to have been a supplicatory ritual, in which God was beseeched to bestow 'enduring power [and] established good fortune' upon the king. If so, then the half-figure might represent a priest or bishop, and the decorated golden band around the neck of his robe his liturgical stole. Alternatively, it may be significant 
that the figure's beard and long hair falling over his shoulders are also to be found in the representations of rulers in the ceiling - thus raising the possibility that the scene may evoke a ceremony in which the king either prayed to God for lasting power and good fortune, or blessed the assembly on the model of Byzantine imperial practice. In that case, the decorated golden band might represent the royal loros. The location of the panel in the immediate vicinity of the throne platform strengthens the possibility that it may refer to a royal ceremony. Were this to be so, then this panel would belong to a group of approximately ten genre scenes that depict life in King Roger's palace, ${ }^{43}$ but would be the only one to refer to a ceremony that was actually performed within the western hall of the Cappella Palatina - and the only one in which image and text were employed in self-reference.

No contemporary witness confirms that the lists of $a d^{\text {‘ }}$ iya or supplications that dominate the surviving Arabic inscriptions from Norman Sicily were ever recited aloud, but the texts themselves suggest that they may have been intended for public performance. The inscription from King Roger's mantle is composed in rhymed prose or $s a j^{\prime}$, which breaks up the text into a series of short, rhyming couplets that would have been suitable for recitation aloud as a litany of royal blessings:

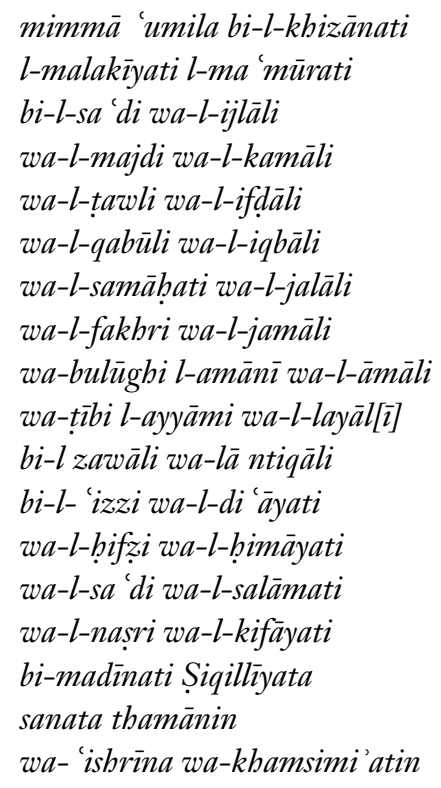

("This was made in the most royal, flourishing wardrobe, with good fortune, magnificence, splendour, perfection, might, superiority, generosity, prosperity, propitious fate, dignity, glory, beauty, attainment of desires and hopes, pleasure of days and nights without end or removal, with power, declaration of faith, vigilance, protection, good fortune, security, victory and capability, in the city of Sicily, in the year five-hundred and twenty-eight [ I I $33-4 \mathrm{CE}]$ ") 44 
The supplications inscribed on the ceilings of the Cappella Palatina are not composed in $s j^{\prime}$, and the individual texts are too short to be considered to be litanies, but the lexical repertoire is much the same as that used for the inscription on Roger's mantle. ${ }^{45}$ Were all the ad 'iya in the ceilings to be read together as a single continuous text, they would assume the cadence and shape of a litany. The case is not proven, but the evidence is sufficient to keep it open. No contemporary source helps us identify who might have recited such a litany but, if anyone, it would have been the royal courtiers, whether those standing bodily before the king or those imagined in the paintings of the ceiling. Such a litany might have been understood to have been spoken by the building itself, rather in the way in which the palace addressed the verses in the opus sectile inscriptions to an individual courtier. In this case, of course, the ad 'iya are supplications addressed to God - prayers of praise that were intended to be overheard by the king and his courtiers.

\section{AUDIENCE AND LEGIBILITY}

So far, the legibility of the Arabic inscriptions in the Cappella Palatina has not been discussed, although the majority of visitors to the chapel would have been unable to read them as texts. This apparently straightforward claim, however, is complicated both by variety in the content, form and location of the inscriptions themselves and by the range of readers and viewers.

A first distinction may be made between those able and unable to read Arabic. In the twelfth century, very few Latin Christians, even educated and highly trained officials of the royal court and administration, would have been able to read Arabic. ${ }^{6}$ The only significant exceptions - Arab and Berber Muslims who had converted or been converted to the Latin rite - seem to have been crypto-Muslims. A much larger number of Greek Christians native to Sicily and Calabria would have been able to read Arabic, and many of the leading officers of the court and administration were drawn from this group. A few Greek Christians from outside the island, such as King Roger's chief minister, George of Antioch, one of the chief architects of the multicultural Sicilian monarchy, were also able to read Arabic. Many Jews would have been able to read Arabic, but I dare say that none were royal courtiers. But by far and away the largest group who would have been able to read the inscriptions in the Cappella Palatina were educated Muslims, amongst whom five groups may be distinguished. First were the scholars and men of letters, such as the geographer al-Idrīisi and the poets 'Abd al-Raḥmān al-Buthīrī and 'Abd al-Raḥmān al-Ițrābanishī, who were attracted to the Norman court by the patronage of the king and of his leading officials. The author or authors of the verses in the opus sectile inscriptions may well have belonged to this group. Second were other elite visitors to the Norman court, including ambassadors from Fatimid Cairo and from other 
Islamic rulers. A letter borne by one such ambassador from the caliph al-Hāfiz li-dīn Allāh (I I I-49) to King Roger demonstrates how closely Cairo monitored the use of Arabic by the Norman court. 47 Third were the leaders of the

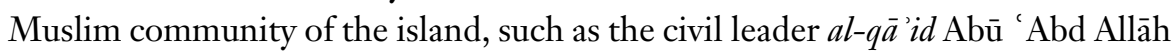
Hammūd, himself a patron of men of letters, and the Banū Rajā' who provided the $q \bar{a} \bar{d} \bar{\imath}$ of Palermo in three successive generations. ${ }^{4}{ }^{8}$ Fourth were the 'men of the pen', the administrators, secretaries and scribes employed in the royal dīwann, a mixed group that could include both leaders of the Muslim community and crypto-Muslim eunuch slaves who had been educated and trained within the royal court and administration. ${ }^{49}$ Finally, and perhaps most problematically, are those who made the inscriptions - metalworkers, painters and stonemasons. All of the inscriptions, except perhaps the pseudo-inscriptions, were designed by more or less highly skilled calligraphers who are perhaps unlikely to have been the craftsmen themselves, but rather either the distant artists of traditional 'kufic' designs preserved in the painters' portfolios or the contemporary artists of new epigraphic designs in cursive script - there is reason to conclude that both groups were responsible for the epigraphic designs painted in the Cappella Palatina. $5^{\circ}$ Contemporary calligraphers may very well have come from the first group of visiting men of letters or from the fourth group of 'men of the pen' employed within the palace.

Although members of all five of these groups would have been more or less able to read the Arabic texts inscribed in the Cappella Palatina, that does not mean that they all actually did so. For example, the opus sectile inscriptions in the Cappella Palatina (Fig. 40) and in the royal palace in Messina are written in large cursive script, with the dark green inlaid characters contrasting strongly with the white marble matrix. They seem to have been placed around the doorways giving entrance to the palace and were thus both highly visible and perfectly legible..$^{\text {I }}$ Nonetheless, the manner in which they originally combined horizontal lines of text with vertical ones that might run from top to bottom or from bottom to top meant that even a man of Arabic letters would first have had to puzzle out their arrangement before he could have begun to read their content. Even when he had done so, the juxtaposition of verses in different metres created a series of intratextual obstacles that he would have had to overcome before he could have accessed their meaning. Today, this is difficult enough to do seated undisturbed at a desk, with the texts spread out in front of one. How much more difficult would it have been for an ambassador or a courtier passing nervously through a doorway into the presence of the king? In much the same way, the text of the long list of $a d$ ' iya embroidered in gold on the hem of King Roger's mantle could only have been read when it was displayed fully open, as it is today in the Weltliche Schatzkammer in the Schweizerhof in Vienna..$^{2}$ In the twelfth century, perhaps only its designer and the embroiderers who made the mantle, as well as the servants who cared for it in the royal wardrobe, would have had the opportunity to read its inscription - and, of course, only those of them who could read Arabic. 
One is drawn towards the conclusion that only the poet who composed the verses, and perhaps the officials who commissioned these inscriptions and oversaw their installation, would ever have actually read them on the mantle itself. We cannot even be sure that the embroiderers could read the words created by their own fingers. However, as we have already seen, the rhymed prose inscription on the border of Roger's mantle seems to be composed for recitation, whereas the verses inscribed in opus sectile are likely to have been recited at least on their inauguration. Their content may thus have reached an audience far greater than those who actually read the inscribed texts.

Let us turn now to consider the impact of the Arabic inscriptions in the Cappella Palatina upon those unable to read or understand Arabic. Although nearly all viewers would have recognised them as assertions of royal authority, their reactions to such assertions would have varied greatly according to their ethnic and linguistic community, their political allegiance and their education. William Malconvenant, the younger son of a Norman baron who was struggling to make a career in the trilingual administration and signed his name in a crude kufic script written from left to right, may have looked on his royal master's Arabic inscriptions with approbation and wistful envy. ${ }^{53}$ However, his contemporary, Matthew Bonellus, another Norman baron from Sicily, was one of the leaders of a series of violent revolts against the multicultural ministers of the royal court, which sparked off pogroms against the Muslim citizens, and would have seen the display of Arabic as symptomatic of all that was rotten in the court of Sicily. ${ }^{4}$ Whereas the royal priest Grisandus usurped the royal monopoly to set up a trilingual memorial to his Norman father, and even a quadrilingual monument to his mother, ${ }^{55}$ other Latin churchmen, such as Stephen du Perche, archbishopelect of Palermo, disapproved so strongly of the Saracen ways tolerated in Sicily that he wrote to Pope Alexander III urging him to intervene..$^{6}$ Not only would the Arabic inscriptions in the Cappella Palatina have been viewed in very different ways by such diverse individual viewers but those viewers are likely to have displayed their reactions in very different ways according to whether they were in the presence of the king and his ministers or alone in the company of their most trusted friends.

Given that no contemporary source discusses the use of Arabic inscriptions by the Norman kings of Sicily - except for Al-Idrīsī and Ibn Jubayr in the brief passages cited later - there is perhaps little more to be said about audience and legibility, but the following brief discussion addresses the illegibility of most of the surviving Arabic inscriptions in the Cappella Palatina.

\section{ILLEGIBILITY}

The Greek and Latin texts in the mosaics of the Cappella Palatina are easily legible to the extent that they are written clearly and more or less correctly, and 
they can be read from the pavement of the chapel by those with good sight in the natural light of a sunny day. These texts, for the most part the names of saints and verses from scripture, enter into a dialogue with their images, which enhances the legibility of both. In the nave and the two aisles, where individual images and their texts are arranged sequentially to retell the familiar stories of Genesis and the lives of St Peter and St Paul, a familiar sequential narrative further supports legibility.

Seventy-three panels in the painted ceilings now preserve Arabic inscriptions, not counting the four that are part of figural scenes and the many pseudoepigraphic designs, but none is legible in the manner of the Greek and Latin inscriptions. They are located in four areas of the ceilings: two in the borders of the coffers in the aisle ceilings; twenty-three (not counting one pseudoepigraphic design) in the intrados of the deep little niches in the centre of the small units of the muqarnas zone (Fig. 43); thirty in the semi-circular lunettes in the upper tier of the muqarnas zone; and eighteen (including two repainted with pseudo-Arabic in the eighteenth century) in the borders of the star-shaped coffers in the central zone of the nave ceiling (Fig. 4I). ${ }^{57}$

Before electric light and optical lenses, at a time when approximately half of the population in middle age was afflicted by myopia and other impairments to sight, even the largest and most conspicuous inscriptions painted in the ceiling of the nave would have been extremely difficult if not impossible to read from the pavement below. Only at the end of the eighteenth century was it first recorded that the ceiling was decorated with Arabic inscriptions. ${ }^{8}$ When Michele Amari made the first reading and transcription of the texts of the central part of the ceiling of the nave, he did so by using optical lenses, photographs and mirrors to reflect sunlight into the dark recesses of the ceiling; even with such tools, he was unable to read the inscriptions in the niches of the muqarnas zone.59

One sunny day in February 2010, soon after the recent restoration had cleaned them and made them more easily visible than they had been at any time since they were first painted, I was able to read by natural light and with the naked eye the inscriptions bordering the star-shaped coffers in the central section of the ceiling of the nave (Fig. 4I). But I was able to do so only because I am naturally long-sighted and because I already knew from long study of detailed photographs the precise content of each inscription. On the same occasion, I was unable to read the inscriptions in the south aisle even though they are much closer to the pavement than those of the nave; that is because the gold letters do not stand out clearly from the dark blue background and the foliate scrollwork. Nor was I able to read most of the inscriptions in the semicircular lunettes in the upper tier of the muqarnas zone. And I could read none of the inscriptions that decorate the intrados of the deep, little niches in the small units of the muqarnas (Fig. 43). But even though I could not read most of these inscriptions, I could see virtually all of them and recognise them as texts, just as I could see and mistake for texts many more pseudo-epigraphic designs composed of Arabic letterforms without 

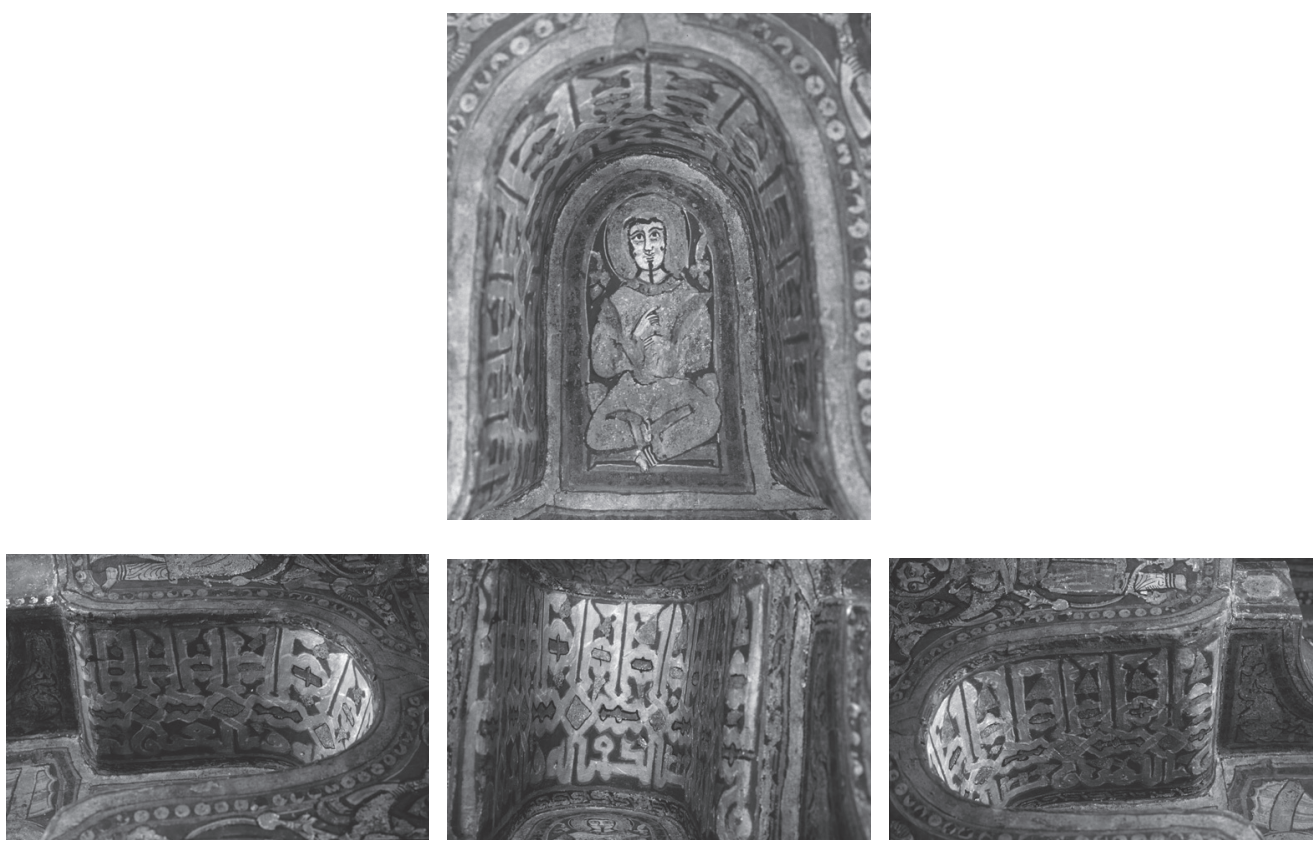

43. Palermo, Palazzo Reale, Cappella Palatina. Details of the Arabic inscription hidden in the intrados of the deep little niche in the centre of the fourth small unit from the west end of the north side of the muqarnas zone: wa-l-yumn wa-l-kifäya wa-l- 'izz wa-l-... ('bliss and capability and power and...') (Khalili Research Centre Archive, Slides nos. ISLi 5 I08, I5 I Iо, I5 I I I, I5 I I 2. (C) 2010 University of Edinburgh \& The Barakat Trust)

literary content. However, I was unable to appreciate the full variety of scripts and the elegance and ingenuity of the calligraphic compositions, in part because the inscriptions are too high to permit the close study of epigraphic and decorative detail, but also because the different forms are too widely dispersed throughout the ceiling to convey any immediate impression of their range and variety.

From the ground, it is nearly impossible for one not already familiar with the inscriptions to distinguish the literary texts from the pseudo-inscriptions. The latter are designs composed of Arabic characters arranged in a pattern, which has no literal meaning and which often breaks the rules of Arabic orthography. The use of pseudo-inscriptions is common to Islamic art in general and owes nothing to the particular context of the Cappella Palatina. The manner in which here, as elsewhere in Islamic art, pseudo-inscriptions tend to be most commonly used to fill the borders of primary decorative elements, including true inscriptions, suggests that they offered an economical solution for the decoration of such marginal panels - allowing the artists to reproduce easily adaptable and infinitely repeatable patterns from their copybooks or memories, rather than more complicated and less adaptable calligraphic compositions with literary content.

With this in mind, let us consider more closely the inscriptions and pseudoinscriptions of one of the eight-pointed stars that fill the octagonal coffers of 
the central zone of the ceiling of the nave (Fig. 4I). ${ }^{60}$ At the centre of the coffer is a eight-lobed dome painted with an intricate, curvilinear strapwork design that radiates outwards from a central eight-pointed star, creating six concentric layers of interstitial spaces, each of a different shape - with the larger ones filled by palmettes, trefoil sprigs and other foliate designs. The central dome is enclosed within two borders that both sit within the cavity of the coffer. The inner border is a rounded moulding decorated as if with a winding rope of two contrasting designs. The outer border is painted with a kufic inscription, with white letters outlined in red, set on a bed of foliated scrollwork on a dark blue ground. The inscription is interrupted at the eight corners by large palmette buds, which effectively address the problem of how the inscription can be made to turn the acute corners. (A transliteration and translation of the text of the kufic inscription have already been given.) The central dome and its two borders together form a composite unit that fits over the stellate cavity at the centre of the octagonal coffer. The transformation of the eight-sided coffer into the eight-pointed cavity is effected by the six bases of stalactite pendants and by the two capitals of the adjoining unit of the muqarnas zone of transition, which form eight obtuseangled projections pointing inwards towards the centre. Four of these projections are painted with pseudo-inscriptions, and four with geometric designs, forming in effect a border along the edge of the stellate cavity. ${ }^{6 \mathrm{I}} \mathrm{In}$ all twenty of the octagonal coffers of the central zone of the ceiling, the equivalent obtuse-angled projections are decorated with an apparently random mix of pseudo-inscriptions and geometric or foliate designs, reinforcing the conclusion that pseudoinscriptions were used in these marginal panels for essentially practical reasons of economy.

If we focus more closely upon one interstice between two points of the star (Fig. 44), we can see how an Arabic inscription in which the textual meaning is perfectly legible - al-sa ' $d w a-l-k a m a \bar{l}$ wa-l-i ... (here seen upside down at the top of the figure) - is juxtaposed with a pseudo-inscription composed of the letter sin attached to an intertwined läm-alif (or alif-läm), which is in turn attached to a letter sin reversed as in a mirror. Not only is the resulting pattern wholly without textual content but also it defies the rules of Arabic orthography.

However, neither the legible Arabic text nor the unreadable pseudo-inscription could have been read from the pavement of the chapel. In effect, without reopening the question of the ability of the audience to read Arabic, both inscription and pseudo-inscription would have been illegible to the twelfth-century viewer.

It is tempting to argue that the primary function of the Arabic inscriptions in the borders of the stellate coffers was not to convey textual meaning, but rather to pick out in white the shape of the eight-pointed stars in the central section, thereby making them particularly conspicuous within the multifaceted and heavily decorated ceiling. That these stellate coffers were recognised as stars in the twelfth century is confirmed by Philagathos Kerameos who remarks that the ceiling 'imitates the heavens when, through the clear air, the host of stars shines 


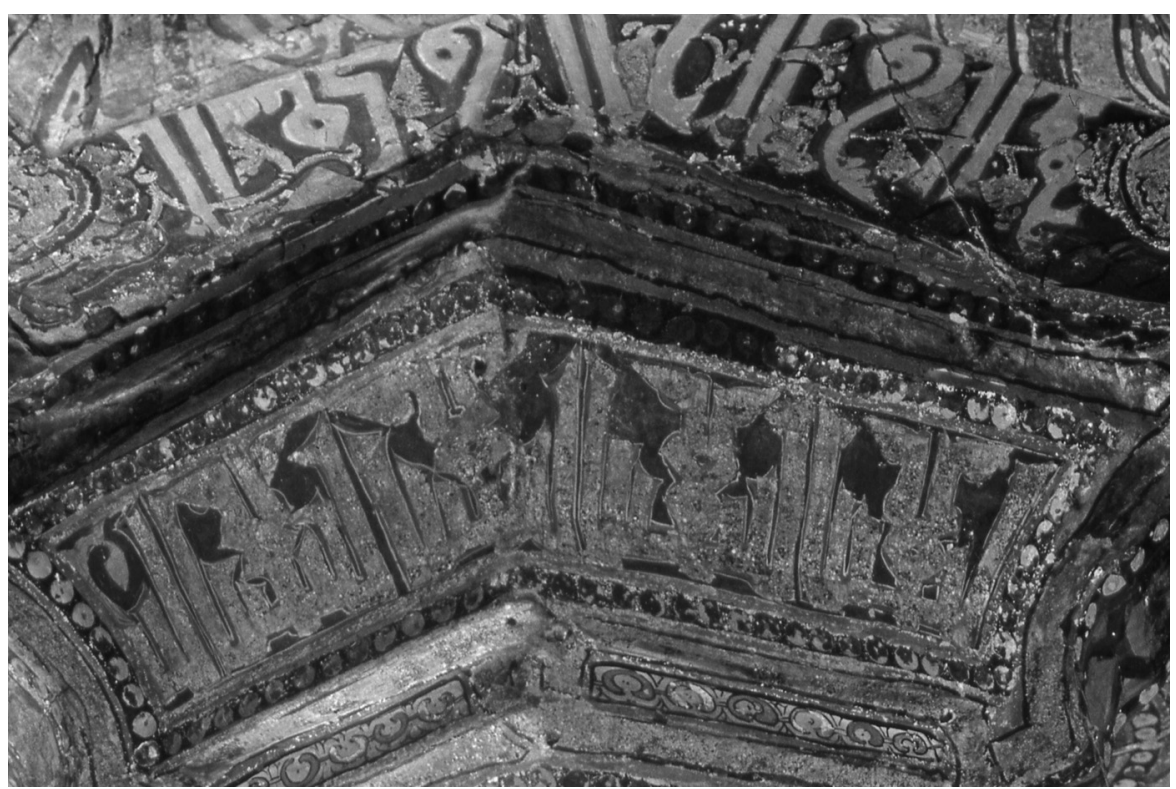

44. Palermo, Palazzo Reale, Cappella Palatina. Detail of a stellate coffer (south side, third from west) from the central zone of the painted wooden ceiling of the nave, showing (below) a pseudo-inscription composed of the letter $\sin$ attached to an intertwined lām-alif (or alif-lām), followed by a reversed letter sin. (Khalili Research Centre Archive, Slide no. ISLi 5784 . (C) 20 IO University of Edinburgh \& The Barakat Trust)

everywhere'. ${ }^{62}$ But the difficulty with this line of argument is that whereas the same visual effect could have been obtained by using a pseudo-inscription or, for that matter, a geometric or foliate pattern, or any other design, so long as it were painted in white or in any pale contrasting colour, the artists went to great pains to outline the stars with a perfectly legible text carefully composed in elegant calligraphy. Moreover, similar Arabic texts decorate the recesses of the muqarnas zone that are almost invisible from the ground, so that these perfectly legible inscriptions cannot be read today even with a powerful torch and binoculars. What is more, the most elaborate and inventive calligraphic compositions in the ceiling are reserved for these invisible recesses, where no one but the artists themselves would have noticed had they used pseudo-inscriptions or even non-epigraphic designs.

The ceiling of the nave of the Cappella Palatina was almost certainly built and painted by a team of itinerant craftsmen according to a model that they had tried and tested many times elsewhere on Islamic palaces and pavilions. It may be that such structures, none of which survive, were significantly lower in height than the nave, so that by transplanting such a ceiling from the hall of an Islamic palace to the nave of the Christian chapel most of its decoration - including its inscriptions - were thereby made illegible. Be that as it may, perfectly legible Arabic inscriptions are frequently located so as to be illegible or invisible even 
in Islamic buildings, so that it would be rash to attribute the illegibility of the Arabic inscriptions in the Cappella Palatina solely to that act of transplantation.

It may be instructive to approach the matter of illegibility from another perspective. We have already seen that the Arabic inscription embroidered in gold on the hem of King Roger's mantle combines the date and place of production with supplicatory formulae similar and in some cases identical to those painted on the ceiling of the Cappella Palatina. Displayed as it is today in the Vienna Schatzkammer, the Arabic text can be read by anyone familiar with the script and the slightly arcane vocabulary, and accustomed to reading $s a j^{6_{3}}$ - skills, incidentally, that only a well-educated man of Arabic letters would have possessed in twelfth-century Palermo. There is no reason, however, to assume that the mantle was ever displayed in this manner at the Norman court, and we know from the coronation ordines of the Norman kings and from other sources that the royal vestments were kept in the wardrobe, under the charge of a special

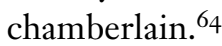

The mantle and the other Norman royal vestments later became part of the ceremonial regalia of the Holy Roman Empire, and contemporary illustrations survive of rulers actually wearing the Sicilian robes. However, Jean Adam Delsenbach's imaginative engravings of various emperors wearing the full regalia give an altogether misleading impression of the legibility of the inscriptions on the regalia and, indeed, of the portability of the vestments. ${ }^{65}$ The artist's primary concern was to document the regalia themselves, not to give a realistic account of how they looked when worn. In fact, the text on Roger's mantle could never have been read, as it were, in situ. Delsenbach pretends that the mantle fell straight from shoulder to floor without a single fold, exhibiting the text as if it were inscribed on a rigid canopy, when of course it would have been hidden within folds that would have moved continuously with the wearer. What is more, the mantle weighs a knee-trembling fifty kilograms, and few men could have stood still long enough for would-be readers on their hands and knees to crawl about trying to decipher the inscription. Albrecht Dürer's far more impressionistic reconstruction of Charlemagne wearing the Sicilian vestments may be closer to reality; it may even be significant that Dürer seems not to have recognised the inscription as meaningful text. ${ }^{66}$

If the relatively clear and large inscription on the mantle could not have been read while it was being worn by the king, still less could the much smaller and poorly executed inscriptions in Latin and cursive Arabic script on his alba have been read in situ, hidden as they were not just by the folds of the garment but also by the mantle and the stole. ${ }^{67}$ And, of course, no observer could have read the inscription on the leggings while they were being worn, for not only does the text begin on one leg and continue on the other but also the leggings would have been completely hidden by the successive layers of the mantle, alba and tunic. ${ }^{68}$

Thus the regalia of the Norman kings bore perfectly legible Arabic inscriptions that, like those in their palace chapel, would ordinarily have been 
completely illegible even to those few of their courtiers who possessed the linguistic skills that would have enabled them to read them.

These inscriptions principally operated not as texts but as signifiers that conveyed not through content but by form a complicated nexus of messages about the nature of the Norman monarchy to a diverse audience. The use of Arabic in these royal media proclaimed first and foremost that the king was master of the Arabic language and, by extension, of all other aspects of Arab and Islamic culture. Although Arabic inscriptions on royal coins, documents and inscriptions successfully created the impression that the kings themselves had mastered the language, there is little doubt that they were in fact unable to read and write Arabic. ${ }^{69}$ Contemporaries nonetheless regarded the kings' mastery of Arabic as a marvellous and potentially threatening demonstration of their authority and power. Ibn Jubayr, a Spanish Muslim visitor to the court of William II, wrote, 'May God protect the Muslims from [the king's] enmity and ability ('ádiyata- $b u$ wa-bastata-bu); amongst the marvellous things told about him is that he reads and writes in Arabic'. $7^{\circ}$ Similarly, the variety of Arabic scripts employed by King Roger on a variety of media had been noted by al-Idrīisi, the author of the geographical work sometime referred to as the Kitäb Rujār ('Book of Roger'). Of Palermo cathedral, he remarks that 'it is difficult to comprehend the marvellous workmanship, the artful choice and inventive wonders of the range of images, and the varieties of ornaments and inscriptions'. And, although he does not mention the Cappella Palatina itself, he describes how the royal palace was 'constructed and adorned with most wonderful curiosities (bi-a 'jabi l-mughtaribāt) and filled with things of extraordinary character ( $b a d \bar{a}$ ' $i$ ' $a l$ siffāt $)^{\prime}$, phrases that, as Michele Amari assumed, may refer respectively to calligraphy and representational images. $^{7 \mathrm{I}}$

\section{TOWARDS SOME CONCLUSIONS}

The variety of different forms of the Arabic script used in the Cappella Palatina indicated the king's mastery over all things Arab and Islamic, and the juxtaposition of Arabic with Greek and Latin scripts reminded the viewer that it was not just Arabic that the king claimed to have mastered. In the royal chapel, as in bilingual coins from the royal mint, bilingual documents from the royal chancery, and multilingual inscriptions on royal buildings and erected by royal servants, the Norman king proclaimed not only his mastery of the three individual cultures of the island but also that Arab, Greek and Latin had been merged under his beneficent rule into a single populus trilinguis. But other forces also governed the use of Arabic inscriptions in the Cappella Palatina. The strongest were the artistic traditions respected by the painters of the ceilings. The inscriptions and pseudoinscriptions belonged to their stock repertoire. The content, location and form of the inscriptions were largely determined by what the painters had done time 
and time before, presumably for Muslim patrons, and had brought with them to Norman Palermo. Such traditions incorporated tried and tested solutions to practical artistic challenges: visual - how to emphasise the stellate outline of the coffers of the central zone; economic - how to save time and skilled labour in the decoration of marginal zones; and physical - how to decorate the intricately multifaceted surfaces of the ceiling while precariously balanced on a rickety scaffolding more than ten metres above the ground. In contrast, the polychrome inlaid stone inscriptions from the west end of the royal hall, supplemented by the similar fragments from the royal palace in Messina, illustrate the most extreme departure from tradition by King Roger's epigraphers. Both the technique of opus sectile and the outlandish cursive ductus of these inscriptions are unique to Norman Sicily; the former borrows from South Italian ecclesiastical decoration, the latter perhaps mirrors the administrative script used in the royal dīwān. Visuality again predominates: here, close to the royal throne, a conspicuous display of porphyry and serpentine is strongly contrasted against a white marble background. The verses themselves, except for the inclusion of the barbaric name of Rujār, demonstrate an unimaginative, if wholly competent, adherence to the traditions of Arabic panegyric. But, by addressing visitors to the palace in the imperative voice, they seek to prescribe their approach to the palace, as if it were the Meccan sanctuary or a paradise on earth. Even the repetitive lists of $a d^{\text {' }}$ 'ya painted in the ceilings may evoke litany-like acclamations performed as part of the public presentation of the king. All of these motive forces - the proclamation of royal policy, practical artistic traditions, and what may be regarded as some sort of performative utterance - simultaneously drove the Arabic inscriptional programme in the Cappella Palatina.

\section{NOTES}

I. Antonio Braca, Il Duomo di Salerno: Architettura e culture artistiche del Medioevo e dell'Età Moderna (Salerno, 2003), 2 I5:... ROBBERTUS DUX R[omani] IMP[erii] MAXIM[us] TRIUMPHATOR DE ERARIO PECULIARI.

2. André Guillou, Recueil des inscriptions grecques médiévales d'Italie, Collection de l'École française de Rome 22 (Rome, I996), 2 Iо-

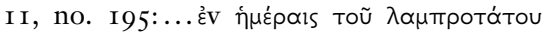

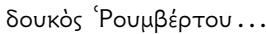

3. Lucia Travaini, La monetazione nell'Italia normanna, Istituto Storico Italiano per il Medio Evo Nuovi Studi Storici 28 (Rome, I995), ro9-10, 398-9, no. 6r.

4. Travaini, Monetazione, Iо9-1 Iо, 398-399, no. 6r: lā illab illā allāb mubammad rasūul allāb / muḅammad rasūl allāh arsalabu bi-l-budā wa-dìn l-ḅaqq li-yuzhirabu 'alā l-dīn kullibi ('There is no god except God. Muhammad is the messenger of God. / He sent him with guidance and the religion of truth to cause it to prevail over all religions').

5. For this assertion, see the following, all with extensive further bibliography: Jeremy Johns, Arabic Administration in Norman Sicily: The Royal Dīwān, (Cambridge, 2002), especially pp. 284-300; Alex Metcalfe, Muslims and Christians in Norman Sicily. Arabic speakers and the end of Islam (London, 2003), especially 99I I 3 ; J. Johns, "L'iscrizioni arabe dei re normanni di Sicilia: una rilettura," in Nobiles officinae: perle, filigrane e trame di seta dal Palazzo Reale di Palermo, 2 vols., ed. Maria Andaloro (Catania, 2006), 2.47-67; Eng. trans., 2.324-37. See also Karla Malette, "Translating Sicily," Medieval Encounters 9 (2003), I4O63.

6. Peter of Eboli, Liber ad honorem Augusti sive de rebus Siculis, f.97v., ed. Theo Kölzer and 
Marlis Stähli (Sigmaringen, I994), 44-5: urbs felix, populo dotata trilingui; illustration of the trilingual chancery, 59 (f. Iorv.).

7. For a general discussion of the Arabic inscriptions of the Norman rulers, with up to date bibliography, see Johns, 'L'iscrizioni arabe dei re normanni,' in Nobiles officinae, ed. Andaloro, 2.47-67; Eng. trans., 2.324-337.

8. For the quadrilingual inscription in which Arabic, Greek, Latin and Hebrew scripts are used as symbols for the four religious communities of Sicily - Muslim, Greek Orthodox, Latin Catholic and Jewish, see J. Johns, 'Lapidi sepolcrali in memoria di Anna e Drogo, genitori di Grisanto, chierico del re Ruggero,' in Nobiles officinae, ed. Andaloro, I.519-23; Eng. trans., I.775-8.

9. Eugenius of Palermo, Versus iambici XXIV. 65-9, ed. Marcello Gigante, Istituto siciliano di studi bizantini e neoellenici, Testi e Monumenti, Testi ro (Palermo, I964), I30; It. trans. 163-4.

Io. For the most up-to-date and comprehensive accounts of the Cappella Palatina, see the superb photographs accompanied by descriptive schede and analytical essays in $L a$ Cappella Palatina a Palermo, Mirabilia Italiae I 5, 4 vols., ed. Beat Brenk (Modena, 2010). See also the studies collected in Die Cappella Palatina in Palermo - Geschichte, Kunst, Funktionen. Forschungsergebnisse der Restaurierung Hg. im Auftrag der Stiftung Würth, ed. Thomas Dittelbach (Künzelsau, 20I I).

I I. For a comprehensive catalogue and discusssion, see J. Johns, 'Iscrizioni arabe nella Cappella Palatina,' in Cappella Palatina, ed. Brenk, I. $353-86$.

I2. J. Johns, 'Lastra con iscrizione trilingue di Pietro (Barrūn) il Gaito, eunuco alla corte di Ruggero II,' in Nobiles officinae, ed. Andaloro, I.5IO-II; Eng. trans., I.77I-2. See also the objections of A. Nef, Conquérir et gouverner la Sicile islamique aux XIe et XIIe siècles, Bibliothèque des Écoles françaises d'Athénes et de Rome, fasc. 346, Rome, 201 I, pp. 335-36, that are refuted in $\mathrm{V}$. von Falkenhausen, N. Jamil and J. Johns, 'The twelfth-century documents of St. George's of Tròccoli (Sicily)', forthcoming, note 82 .

I 3. J. Johns, 'Lastra con iscrizione trilingue dalla clessidra di re Ruggero,' in Nobiles officinae, ed. Andaloro, I.5 I2-I3; Eng. trans. I.772773. Johns, 'Iscrizioni arabe nella Cappella Palatina,' r.382-3.

I4. J. Johns, 'Tre lastre frammentarie con iscrizioni arabe in lode di Ruggero II dal palazzo di Palermo,' in Nobiles officinae, ed. Andaloro,
I.499-50I; Eng. trans. I.765-6. Johns, 'Iscrizioni arabe nella Cappella Palatina,' I. $379-82$.

I 5. Annliese Nef, 'Venti blocchi frammentari con iscrizioni arabe in lode di Ruggero II dal palazzo di Messina,' in Nobiles officinae, ed. Andaloro, I.502-9; Eng. trans., I.766-70.

I6. For the mantle, see: William Tronzo, 'The Mantle of Roger II of Sicily,' in Stewart Gordon, Robes and Honor. The medieval world of investiture (New York, 200I), 24I-253; Oleg Grabar, 'The experience of Islamic art,' in Irene A. Bierman, The Experience of Islamic Art on the Margins of Islam (Los Angeles, 2005), I I-59; Rotraud Bauer, 'Manto di Ruggero II,' in Nobiles officinae, ed. Andaloro, I.45-9; Eng. trans. I.577-9. See also notes $65-8$.

I7. Johns, 'L'iscrizioni arabe dei re normanni,' 47-8; Eng. trans. 324 .

I8. Johns, 'Iscrizioni arabe nella Cappella Palatina,' $\mathrm{I} \cdot 355^{-79}$.

I9. See the collections of recent studies (and the secondary works listed therein) cited in note Io.

20. Johns, 'Iscrizioni arabe nella Cappella Palatina,' $1.383^{-6 .}$

2I. See note I4.

22. For this relative date, see J. Johns, 'The Date of the Ceiling of the Cappella Palatina in Palermo,' in Ernst J. Grube and J. Johns, The Painted Ceilings of the Cappella Palatina, Islamic Art Supplement I (Genova and New York, 2005), 6-7. See also the work cited in note 23.

23. J. Johns and Stefano Riccioni, Schede nos. I6I, 37 I and 475, in Cappella Palatina, ed. Brenk, 2.440-I, 490-I, $55^{\mathrm{I}-5}$.

24. Johns, 'Iscrizioni arabe nella Cappella Palatina,' I.355-79.

25. Maria Pia Demma, 'Cofano con figure intarsiate e iscrizione nash,' in Nobiles officinae, ed. Andaloro, I.136-9. For a less than wholly satisfactory reading and Italian translation of the inscriptions: Michele Amari, Le epigrafi arabiche di Sicilia, trascritte, tradotte e illustrate, and ed., rev. Francesco Gabrieli (Palermo, I97I), 290-309.

26. 'A great many curtains are hung, the fabric of which is threads of silk, woven with gold and various dyes, that the Phoenicians have embroidered with wonderful skill and elaborate artistry': from the ekphrasis of the Cappella Palatina by Philagathos Kerameos, trans. Johns, 'The Date of the Ceiling,' I3I4; see also Johns' discussion of this passage, 4 and 6. Hangings are shown in the 
illustration of the Cappella Palatina by Peter of Eboli, Liber ad honorem Augusti, eds. Kölzer and Stähli, 43 (f. 97r.).

27. Compare the illustrations of the Cappella Palatina by Peter of Eboli, Liber ad honorem Augusti, eds. Kölzer and Stähli, 43 (f. 97r.) and 47 (f. 98r.), and the painting of the Cappella Palatina in the north muqarnas zone of the ceiling of the nave discussed by Johns, Fig. 59I and Scheda no. 59I, in Cappella Palatina, ed. Brenk, 2.58I-2 and 4.459, fig. 59I.

28. Andaloro, ed., Nobiles officinae, I.44-9, 559, 60-I. Tarif Al Samman, 'Arabische Inschriften auf den Krönungsgewändern des Heiligen Römischen Reiches,' Jabrbuch der kunsthistorischen Sammlungen in Wien 78 (1982), 7-34, with discussion in Johns, 'Iscrizioni arabe dei re normanni,' 2.47-67; Eng. trans., $2.324-36$. See also the works cited in note 16 , and notes $65^{-8}$.

29. See note 13 .

30. J. Johns, 'The Greek Church and the Conversion of Muslims in Norman Sicily?,' in Stefanos Efthymiadis, Claudia Rapp and Dimitris Tsougarakis, eds., Bosphorus. Essays in Honour of Cyril Mango, Byzantinische Forschungen 2 I (Amsterdam, I995), I4I-2.

3I. Augusta Acconcia Longo, 'Considerazioni sulla chiesa di S. Maria dell'Ammiraglio e sulla Cappella Palatina di Palermo', in

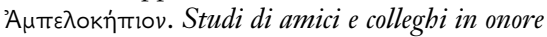
di Vera von Falkenhausen IV, Nea Rhome 4 (Rome, 2007), 267-94.

32. Ernst Kitzinger, The Mosaics of St. Mary's of the Admiral in Palermo (Washington, D.C., I990), $3^{8-9}, \mathrm{I} 3 \mathrm{I}$.

33. Johns, 'Tre lastre'.

34. Ibn Jubayr al-Kinānī, Abū 1-Husayn Muhammad ibn Aḥmad, Rị̣lat al-Kinānī, ed. Michael Jan de Goeje and William Wright (Oxford, I907), 325: kafà llābu l-muslimina 'ádiyata-bu wa-bastata-bu wa-min 'ajībi sha 'ni-bi l-mutahaddathu bi-bi anna-bu yaqra'u wa-yaktubu bi-l-'arabiya. See also p. 26 and note 70 .

35. For the most recent discussion of these, with earlier bibliography, see the works cited in note I4.

36. Nef, 'Venti blocchi,' 505, no. 3. The verb $(u d k b u l \bar{u})$ is the masculine plural of the imperative mood.

37. Johns, 'Iscrizioni arabe nella Cappella Palatina,' I. 377 , and 4.73 o, fig. I 045 .

38. Johns, 'Iscrizioni arabe dei re normanni,' 2.56, and 2.67, tav. III; Eng. trans. 2.328, and 2.337, Table III. See also Johns, 'Iscrizioni arabe nella Cappella Palatina,' I.359-62.
39. Hjalmar Torp, 'Normannerkongen Roger II av Sicilia i lys av bysantinsk og senantikk herskerideologi,' Kongelige Norske Videnskabers Selskabs Forbandlinger (I99I), IOI-I 20. In a similar vein, see also Staale Sinding-Larsen, 'Plura ordinantur ad unum. Some Perspectives regarding the "Arab-Islamic" ceiling of the Cappella Palatina at Palermo (I I 32I I43),' Institutum Romanum Norvegiae, Acta ad archaeologiam et artium historiam pertinentia 7 ( 1989 ) 55-96.

40. Johns, Schede nos. 505-507 (muqarnas unit), 5 I I (male half-figure with two crosses) and 5 I4-I 5 (seated rulers), in Cappella Palatina, ed. Brenk, 2.562, 564-65, 565 .

4I. Three images of drummers have a single Arabic word inscribed on the heads of their drums: see Johns, Scheda no. $38 \mathrm{I}, 2.508$, and figs. 655, 704 and 745, in Cappella Palatina, ed. Brenk, 4.497, 527 and 553 .

42. Vassa Larin, 'The Dikerion and Trikerion of the Byzantine Pontifical Rite: Origins and Significance,' Orientalia Christiana Periodica 74 (2008), 4I 7-30.

43. J. Johns, 'Le pitture del soffitto della Cappella Palatina,' in Cappella Palatina, ed. Brenk, I.400-I.

44. Samman, 'Arabische Inschriften,' 3 I-4. Johns, 'Iscrizioni arabe dei re normanni' 2.53-5; Eng. trans. 2.327.

45. Johns, 'Iscrizioni arabe dei re normanni' 2.67 , tav. III; Eng. trans. 2.337, tav. III (the attentive reader will note that $I$ have since revised the English translation of some of the Arabic ad 'iya: see Johns, 'Iscrizioni arabe nella Cappella Palatina,' I.36I-2).

46. Metcalfe, Muslims and Christians, 99-I I3. Nadia Jamil and J. Johns, 'Signs of the Times: Arabic Signatures as a Measure of Acculturation in Norman Sicily,' Muqarnas 2 I (2004), I 8 I-92.

47. Johns, Arabic Administration, 264.

48. Ibid., 88,89 .

49. Ibid., 2 I 2-56. Metcalfe, Muslims and Christians, 99-I I 3 .

50. Johns, 'Iscrizioni arabe nella Cappella Palatina,' $\mathrm{I} .35^{6-8}$.

5 I. Johns, 'Tre lastre'. Nef, 'Venti blocchi'.

52. Samman, 'Arabische Inschriften,' 3 I-4 and figs. I 5-I9.

53. Jamil and Johns, 'Signs of the Times,' i 84-6.

54. For Bonellus, see Graham A. Loud, ed. and trans., The History of the Tyrants of Sicily by 'Hugo Falcandus'. Manchester Medieval Sources (Manchester, I998), 2 I, 86, 92-104, Iо7-8, I IO-I 2, I I 5-20, I 22-4, I 97, 229-32.

55. Johns, 'Lapidi sepolcrali'. 
56. Johns, Arabic Administration, 229 and note 68.

57. Johns, 'Iscrizioni arabe nella Cappella Palatina,' I.355-79.

58. Johns, 'Le pitture del soffitto della Cappella Palatina,' r.389.

59. Ibid., I.389-90.

6o. Johns, 'Iscrizioni arabe nella Cappella Palatina,' I.377, and 4.73 o, fig. I045.

6I. Note, however, that the hastae of the kufic inscription radiate outwards, obeying the norm for the arrangement of inscriptions that circumscribe a central space, whereas those of the pseudo-inscriptions point inwards towards the centre of the star. This may indicate that the artists or designers conceived of the pseudo-inscriptions as belonging to the decorative scheme of the stalactite pendants rather than of the stellate domes.

62. Johns, 'The Date of the Ceiling,' I 3.

63. See the works cited in note $\mathbf{r} 6$.

64. R. Elze, 'Tre ordines per l'incoronazione di un re e di una regina del regno normanno di Sicilia,' in Atti del congresso internazionale di studi sulla Sicilia normanna (Palermo 4-8 dicembre 1972), Istituto di Storia Medievale, Università di Palermo, I973, B, sections 4-5, $2 \mathrm{I}$.

65. Beatrix Kriller, 'Delineation exacte des Orneméns Impériaux du Sainte Empire Romain et Allemand. Gardés dans la ville libre et impériale de Nuremberg. Dessinés et gravés aux dépens de Feu Monsieur Le Sénateur ferôme Guillaume Ebner d'Eschenbach, par Jean Adam Delsenbach. Avec les Saintes Reliques gravées d'après les dessins de Fréderic Iuvenell,
Nuremberg, Gottlieb Schneider I790, in Nobiles officinae, ed. Andaloro, r.84-87; Eng. trans., I.592-3.

66. Mathias F. Müller, 'Carlo Magno con le vesti dell'incoronazione del Sacro Romano Impero,' in Nobiles officinae, ed. Andaloro, I.80-I; Eng. trans., I.590-I.

67. Rotraud Bauer, 'Alba di Guglielmo II,' in Nobiles officinae, ed. Andaloro, I.55-9; Eng. trans., I.580-2. Samman, 'Arabische Inschriften,' I $9^{-24}$.

68. Rotraud Bauer, 'Calze di Guglielmo II,' in Nobiles officinae, ed. Andaloro, r.6r; Eng. trans., I.582-3. Samman, 'Arabische Inschriften,' $25-3 \mathrm{I}$.

69. Jamil and Johns, 'Signs of the Times,' I $82-$ 4. Vera von Falkenhausen, 'Una Babele di lingue: a chi l'ultima parola? Plurilinguismo sacro e profano nel regno normanno-svevo,' Archivio storico per la Calabria e la Lucania 76 (2010), 23. For a rather different reading of the same evidence, see Metcalfe, Muslims and Christians, I02-4.

70. Ibn Jubayr, Ribla, 325 . See also note 34 .

71. Abū 'Abd Allāh Muhammad ibn 'Abd Allāh ibn Idrīs al-Hammūdī al-Hasanī Al-Idrīsī, Opus Geographicum sive 'Liber ad eorum delectationem qui terras peragrare studeant' (Kitab nuzhat al-mushtaq), ed. Antonio Bombaci et al. (Naples, I970-6), p. 59I; Michele Amari, Biblioteca arabo-sicula, ossia raccolta di testi Arabici che toccano la geografia, la storia, la biografia e la bibliografia della Sicilia. Raccolti e tradotti in Italiano, and ed., rev. Umberto Rizzitano et al., 3 vols. (Palermo, I997-8), I.59. 